UDK $577.1: 61$

ISSN 1452-8258

J Med Biochem 37: 456-464, 2018

Original paper

Originalni naučni rad

\title{
SERUM CONCENTRATION OF HEPCIDIN AS AN INDICATOR OF IRON RESERVES IN CHILDREN
}

\author{
KONCENTRACIJA SRUMSKOG HEPCIDINA KAO INDIKATORA REZERVI GVOŽĐA U DECE
}

\author{
Jelena Ćulafić ${ }^{\text {, Jovanka Kolarović }}$, Lato Pezo ${ }^{2}$, Velibor Čabarkapa3,4, Stanislava Nikolić3,4, \\ Aleksandra Stojadinović ${ }^{1}$, Marija Bodroža Solarov ${ }^{5}$ \\ ${ }^{1}$ Faculty of Medicine, University of Novi Sad and Institute for Child and Youth Health Care, Novi Sad, Serbia \\ ${ }^{2}$ University of Belgrade, Institute of General and Physical Chemistry, Belgrade, Serbia \\ ${ }^{3}$ Department of Pathophysiology and Laboratory Medicine, Faculty of Medicine, \\ University of Novi Sad, Novi Sad, Serbia \\ ${ }^{4}$ Center for Laboratory Medicine, Clinical Center of Vojvodina, Novi Sad, Serbia \\ ${ }^{5}$ Institute of Food Technology, University of Novi Sad, Novi Sad, Serbia
}

\begin{abstract}
Summary
Background: Anemia represents a significant cause of maternal and perinatal mortality, as well as child mortality. The aim of the research was to determine the serum concentration of hepcidin in children aged 6 months to 2 years and adolescents aged 11 to 19 years which suffer from iron deficiency anemia and compare it with the serum concentration of hepcidin in the control groups, as well as to determine its connection with the parameters of the iron metabolism.

Methods: The research included 173 examinees, 89 of them suffered from iron deficiency anemia and 84 did not suffer from iron deficiency anemia (the latter represented the control group). Blood samples were collected from all study participants. The samples were analyzed for complete blood count and parameters of iron metabolism. ELISA method was used for establishing serum hepcidin levels.

Results: The research showed that the concentration of hepcidin is statistically lower in children $(4.4 \mathrm{ng} / \mathrm{mL})$ and adolescents $(4.1 \mathrm{ng} / \mathrm{mL})$ who suffer from iron deficiency anemia in comparison with the control group $(14 \mathrm{ng} / \mathrm{mL}$, $10 \mathrm{ng} / \mathrm{mL}$, respectively). The positive correlation between serum hepcidin level and iron in the serum, ferritin, the
\end{abstract}

\footnotetext{
Address for correspondence:

Jovanka Kolarović, MD, PhD, Professor

Institute for Child and Youth Health Care

Faculty of Medicine, University of Novi Sad

Hajduk Veljkova 1, 21000 Novi Sad, Serbia

Tel: +381641615804

e-mail: jovanka.kolarovic@mf.uns.ac.rs
}

\section{Kratak sadržaj}

Uvod: Anemija predstavlja značajan uzrok maternalnog i perinatalnog mortaliteta, kao i moratliteta dece. Cilj istraživanja je bio da se odredi serumska koncentracija hepcidina u dece uzrasta od 6 meseci do 2 godine i adolescenata uzrasta od 11 do 19 godina koji boluju od sideropenijske anemije i uporedi sa serumskom koncentracijom hepcidina u kontrolnim grupama, kao i da se odredi njegova povezanost sa parametrima koji ukazuju na metabolizam gvožđa. Metode: Istraživanjem je obuhvaćeno 173 ispitanika, 89 ispitanika koji su bolovali od sideropenijske anemije i 84 koji nisu bolovali od sideropenijske anemije (koji su predstavljali kontrolnu grupu). Krv je uzorkovana svim ispitanicima. Iz uzoraka je određivana kompletna krva slika i vrednosti parametara metabolizma grožđa. Nivo hepcidina u serumu je određivan ELISA metodom.

Rezultati: Istraživanjem je pokazano da je koncentracija hepcidina statistički značajno niža kod dece $(4,4 \mathrm{ng} / \mathrm{mL})$ i adolescenata $(4,1 \mathrm{ng} / \mathrm{mL})$ koji boluju od sideropenijske anemije $u$ poređenju sa kontrolnom grupom $(14 \mathrm{ng} / \mathrm{mL}$, odnosno $10 \mathrm{ng} / \mathrm{mL}$, po redosledu navođenja). Potvrđena je pozitivna korelacija između concentracije hepcidina i gvožđa u serumu, feritina, srednjeg volumena eritrocita i

List of abbreviations: ANN, Artificial neural network; ANOVA, Analysis of variance; CRP, C-reactive protein; $\mathrm{Hb}$, Hemoglobin; $\mathrm{Fe}$, Iron; FOP, First order polynomial model; IDA, Iron deficiency anemia; $\mathrm{MCH}$, Mean corpuscular hemoglobin; MCHC, Mean corpuscular hemoglobin concentration; MCV, Mean corpuscular volume; PLT, Platelets; RBC, Red blood cells; Rtc, Reticulocytes; TIBC, Total iron binding capacity; Trans, Transferrin; TSAT, Transferrin saturation; UIBC, Unsaturated iron binding capacity; WBC. white blood cells; WHO, World Health Organization. 
mean corpuscular volume and transferrin saturation was confirmed, but the negative one occurred in serum hepcidin level, transferrin and reticulocytes.

Conclusions: The age of the examinees does not influence the level of serum hepcidin which makes it a more sensitive indicator of the level of iron in the body. Besides this, serum hepcidin is a reliable biological marker for the assessment of iron deficiency anemia.

Keywords: Anemia, hepcidin, iron deficiency, mathematical modelling

\section{Introduction}

Anemia represents a significant cause of maternal and perinatal mortality, as well as child mortality. Besides, it is also the cause of low birth weight in newborns and leads to psychomotor developmental delay, increases susceptibility to infections and negatively reflects on the economic development of a country due to decreased productivity of the working population. The prevalence of anemia is inversely proportional to the economic development of the country (1).

Iron deficiency represents the major cause of anemia (1-3). It is considered that $50 \%$ of anemia cases in developing countries are caused by iron deficiency (1). According to the World Health Organization (WHO) estimate $47 \%$ of preschool children, as well as $25 \%$ of school children suffer from iron deficiency anemia (4). Children aged from 6 to 24 months (5) and adolescents (6) represent vulnerable groups. The incidence of anemia in adults in Vojvodina region is $7.7 \%$, while data about incidence of anemia in children population is sparse (7).

The most important regulatory role in the iron metabolism is played by hepcidin which makes it a useful biological marker for diagnosing and following iron metabolism disorder (8-10). It functions in the way that it binds to ferroportin (FPN), the only known cell transporter of iron, which is present on the basolateral membrane of erythrocytes, hepatocytes, macrophages and placenta sinciciotrofoblasts (11, 12). FPN represents the product of SLC 40A1gene (13) and consists of 571 amino acids (14). By binding to FPN, hepcidin induces its internalization and degradation, thus reducing intestinal iron absorption and iron release from macrophages (15-17).

So far, there has been no sufficient data that would enable a precise definition of reference values and potential cutoff values which could be a reliable indicator of iron deficiency (18). The number of studies that try to define referential values of hepcidin in children is quite small, and the obtained results are non-homogeneous (19-22).

The objective of this research was to determine the serum concentration of hepcidin in children aged 6 months to 2 years and adolescents aged 11 to 19 saturacije transferina, a negativna između nivoa hepcidina i transferina, kao i retikulocita.

Zaključak: Uzrast ispitanika ne utiče na koncentraciju hepcidina u serumu što ga čini senzitivnijim pokazateljem nivoa gvožđa u organizmu. Osim toga, vrednost hepcidina u serumu predstavlja pouzdan biološki marker u postavljanju dijagnoze sideropenijske anemije.

Ključne reči: anemija, deficit gvožđa, hepcidin, matematičko modeliranje

who suffer from iron deficiency anemia (IDA) and in children of the same age group without IDA. This study aims to establish the correlation of hepcidin concentration and serum iron concentration, ferritin concentration, transferrin concentration, total iron binding capacity (TIBC), unsaturated iron binding capacity (UIBC) and transferrin saturation (TSAT).

\section{Materials and Methods}

The research was conducted in the form of a cross-sectional study at the Institute for Child and Youth Health Care of Vojvodina in cooperation with the Medical Laboratory of the Clinical Center of Vojvodina. The selection of subjects and sampling of blood specimens was performed during 2014 and 2015. The study was approved by the Ethics Committee of the Institute for Child and Youth Health Care of Vojvodina, and conducted in compliance with the Helsinki Declaration.

The research included the total of 173 subjects. All of them were divided into four groups. The first group consisted of 56 children aged 6 months to 2 years who had IDA, defined as $\mathrm{Hb}$ value lower than $110 \mathrm{~g} / \mathrm{L}$ (16 female and 40 male subjects). The second group consisted of 33 adolescents aged 11 to 19 who had IDA (26 subjects were females, and 7 of them were males). This study included female adolescents whose $\mathrm{Hb}$ value was lower than $120 \mathrm{~g} / \mathrm{L}$ or male adolescents whose $\mathrm{Hb}$ value was lower than $130 \mathrm{~g} / \mathrm{L}$. The third and fourth groups were control groups consisting of 32 children aged 6 months to 2 years, i.e. 52 adolescents without IDA.

The study excluded patients who suffered from associated illnesses that affect $\mathrm{Hb}$ concentration in serum, patients in whom the therapy of IDA was initiated and who took medicines that affect iron metabolism.

After the interview with parents and caregivers of all subjects and with adolescent subjects, they signed informed patient consent. Afterwards, blood samples were drawn for the determination of a complete blood count, reticulocytes count, serum concentration of iron, ferritin, transferrin, hepcidin, TIBC, UIBC and for $C$ reactive protein (CRP) (in order to 
eliminate the influence of infection or inflammation on iron, ferritin, transferrin and hepcidin concentracion).

Blood was obtained by venepuncture carried out by trained staff. Samples for hepcidin measurement were centrifuged and immediately stored at $-70{ }^{\circ} \mathrm{C}$ until analysis. Complete blood count was determined by quantitative method of flow cytometry with the application of commercial sets.

Normal values of RBC in the age group 6-24 months were considered to be $3.7-4.5 \times 10^{12} / \mathrm{L}$, and in the age group 11-19 they were $4.1-4.9 \times 10^{12} / \mathrm{L}$. Normal values of $\mathrm{Hb}$ in the age group 6-24 months were considered to be $110-120 \mathrm{~g} / \mathrm{L}$, in the age group 11-19 120-140 $\mathrm{g} / \mathrm{L}$ in female persons and $130-140 \mathrm{~g} / \mathrm{L}$ in male persons. Normal values of $\mathrm{MCV}$ in the age group 6-24 months were considered to be $70-78 \times 10^{-15} / \mathrm{L}$, in the age group 11-19 they were $78-90 \times 10^{-15} / \mathrm{L}, \mathrm{MCH}$ in the age group $6-24$ months was $23-27 \times 10^{-12} / \mathrm{L}$, in the age group 1119 it was $25-30 \times 10^{-12} / \mathrm{L}$ and $\mathrm{MCHC}$ in both age groups was 310-340 g/L. The normal WBC count was $4-10 \times 10^{9} / \mathrm{L}$, PLT count $140-400 \times 10^{9} / \mathrm{L}$, and Rtc count was $0.7-2.2 \%$.

The determination of serum concentration of Creactive protein was performed by the device Roche/Hitachi Cobas C, with the application of commercial sets of Roche Company. Serum iron level was performed photometrically by the device Roche/Hitachi Cobas C, with the application of commercial sets of Roche Company. Normal iron levels in the age group 6-24 months were considered to be 4-25 $\mu \mathrm{mol} / \mathrm{L}$, and in the age group 11-19 they were 5-33 $\mu \mathrm{mol} / \mathrm{L}$. TIBC was determined photomertcally by the device Roche/Hitachi Cobas C, with the application of commercial sets of Roche Company. Normal TIBC value ranges in the age group 6-24 months were considered to be $48-79 \mu \mathrm{mol} / \mathrm{L}$, and in and in the age group 11-19 they were 52-102 $\mu \mathrm{mol} / \mathrm{L}$. Transferrin saturation was calculated according to the following formula: serum Fe $\times 100 /$ TIBC. Cut off value for TSAT which defines IDA is $<15 \%$. Ferritin and transferrin concentrations were determined by immunoturbidimetric method on biochemical analyzer Architect c8000 with commercial sets of Abbott Company (Wiesbaden, Germany).

Normal ferritin concentration value ranges in the age group 6-24 months were considered to be $6-24 \mu \mathrm{g} / \mathrm{L}$, and in and in the age group 11-19 they were $6-40 \mu \mathrm{g} / \mathrm{L}$. Normal transferrin concentration value ranges in the age group 6-24 months were considered to be $2.18-3.47 \mathrm{~g} / \mathrm{L}$, and in and in the age group 11-19 they were $2.33-4.44 \mathrm{~g} / \mathrm{L}$ (10). Hepcidin serum concentration was measured in all subjects. We applied R\&D (Research \& Devlopment) Quantikinine ELISA for the quantitative determination of human hepcidin. The producer neither defined nor recommended the range of reference values. Sensi- tivity of the analysis was $<1.70 \mathrm{pg} / \mathrm{mL}$. The precision of analysis was expressed through the coefficient of variance value $(\mathrm{CV})$, with the precision within one series (intra-assay) CV were $4.3 \%, 3.1 \%$ and $3.2 \%$, respectively, while for the precision among series (inter-assay), CV were even higher: 11\%, $8 \%$ and $6.2 \%$.

\section{Statistical analysis}

All data were processed statistically using the software package STATISTICA 10.0 (StatSoft Inc., Tulsa, OK, USA). Collected data have been subjected to analysis of variance (ANOVA) for the comparison of means, and significant differences are calculated according to post-hoc Tukey's HSD (»honestly significant differences") test at $\mathrm{p}<0.05$ level, 95\% confidence limit.

\section{First order polynomial model}

According to general recommendations, prior to ANN modelling, first order polynomial (FOP) model was developed, and analysis of variance (ANOVA) was performed, in order to check the significant effect of the input variables over the output, as well as to justify the later use of the ANN model by the coefficient of determination $\left(r^{2}\right)$. The FOP model was used for estimation of the main effect of the process variables on responses. The independent variables used for modelling were age, Le, $\mathrm{Er}, \mathrm{Hb}, \mathrm{Tr}, \mathrm{MCV}$, $\mathrm{MCH}, \mathrm{MCHC}$, Fe, UIBC, TIBC, CRP, Ferritin, Trans, Hepcidin, Rtc and Tsat, while IDA was the response variable.

\section{Artificial neural network (ANN) modelling}

Artificial neural network (ANN) models were used for modelling. A multi-layer perceptron model (MLP) consisted of three layers (input, hidden and output). The MLP neural network learns using an algorithm called 'backpropagation'. LevenbergMarquardt algorithm is proved to be the fastest and particularly adapted for networks of moderate size. During this iterative process, input data are repeatedly presented to the network (23). The coefficient of determination $\left(r^{2}\right)$ and SOS were used as parameters to check the performance (i.e. the accuracy) of the obtained ANNs.

\section{Sensitivity analysis}

Sensitivity analysis is a wide accepted technique which is necessary to use for studying the effects of observed input variables and also the uncertainties in obtained models and general network behaviour. On the basis of the developed ANN model, sensitivity analysis was performed in order to more precisely 
define the influence of input variables on the observed outputs.

\section{Results}

The hematological parameters, markers of iron metabolism and CRP are shown in Table I. As expected, hemoglobin, $\mathrm{MCV}, \mathrm{MCH}, \mathrm{MCHC}$, iron, transferrin saturation and ferritin were significantly decreased, while reticulocytes, transferrin, UIBC and TIBC were increased in anemic subjects. RBC and CRP showed no differences among groups.

$\mathrm{MCV}$ and $\mathrm{MCH}$, were significantly lower in both infant groups when compared to the adolescent groups. Iron, ferritin, UIBC, transferin and TSAT were lower in infant control group when compared to the adolescent control group. Observed parameters were similar in both groups with IDA.

Hepcidin was significantly lower in anemic examinees in both infant and adolescent groups (4.4 $\mathrm{ng} / \mathrm{mL}$ vs $4.1 \mathrm{ng} / \mathrm{mL}$ ) when compared to the control groups (14 ng/mL and $10 \mathrm{ng} / \mathrm{mL}$ respectively). Hepcidin concentration was similar when compared between the age groups, both study and control.

In control groups, all the values of measured parameters fell within the reference range with the exception of erythrocyte count in infants and $\mathrm{MCHC}$ in adolescents (slightly elevated).

Table // shows correlation matrix for patients suffering from anemia and control group for 6-24 months and 11-19 years age groups. According to results presented in Table $I$, the serum iron concentration is in a positive correlation with the concentration of ferritin and TSAT, as well as in the negative correlation with UIBC and TIBC, the transferin and Rtc $(p<0.01)$. The serum iron concentration in a positive correlation with the concentration of hepcidin $(p<0.05)$. UIBC is positively correlated with TIBC, transferin and Rtc, while it is in negatively correlated with the concentration of ferritin and the TSAT $(p<0.01)$. TIBC is in a positive correlation with the transferin and Rtc, and in a negative correlation with the concentration of ferritin and TSAT $(p<0.01)$. The concentration of ferritin is in a positive correlation with the concentration of hepcidin and TSAT, and in a negative correlation with the concentration of transferin and Rtc $(p<0.01)$. Transferin is in a positive correlation with Rtc, and in a negative correlation with TSAT $(p<0.01)$, as well as in the negative correlation with the concentration of hepcidin $(p<0.05)$. The concentration of hepcidin in the serum is positively correlated with TSAT, and in a negative correlation with Rtc $(p<0.10)$. Rtc is in a negative correlation with TSAT $(p<0.10)$.

\section{FOP model and the analysis of variance}

Analysis of variance (ANOVA) was conducted for obtained First order polynomial (FOP) model, and output was tested against the impact of input variables (Table III). ANOVA analysis revealed that the parameters Age, RBC, MCH, Transferin and Hepcidin considerably influenced in forming of FOP model IDA calculation, statistically significant at $p<0.01$ level. The coefficient of determination $\left(r^{2}\right)$ for a FOP prediction model of IDA was relatively good (0.753), Table III, indicating that some other model (ANN model, for instance) could improve the validity of the developed model.

\section{Artificial neural network model}

Broyden-Fletcher-Goldfarb-Shanno (BFGS) algorithm, implemented in StatSoft Statistica's evaluation routine, was used for ANN modelling. The optimization procedures to minimize the error function between network and experimental outputs was used during ANN training cycle $(23,24)$, and the sum of squares (SOS) was evaluated according to the BFGS algorithm, to speed up and stabilize convergence of the results (25). ANN models were used to predict experimental variables, reasonably well, for a broad range of the process variables.

The predicted values were very close to the desired values in most cases, in terms of $r^{2}$ value, for ANN models. SOS obtained with ANN models are of the same order of magnitude as experimental errors for outputs reported in the literature $(24,25)$. ANN model is complex because of the high nonlinearity of the developed system $(24,26)$.

The developed empirical models give a reasonable fit to data and successfully predict the IDA of the patient. The first order polynomial model showed high coefficients of determination for prediction of experimental results $(0.753)$, while the artificial neural network model showed better prediction capabilities (overall $r^{2}$ was 0.971).

Sensitivity analysis was performed in order to assess the effect of each change in the output due to the change in the input. It indicates how sensitive is the response variable calculated to the observed domain of input variables.

The influence of the input over the output variables, i.e. calculated changes of output variables for infinitesimal changes in input variables, as well as the importance of an input variable at a given point in the input space are shown in Figure 1. The influence of the input over the output variables, i.e. calculated changes of output variables for infinitesimal changes in input variables, as well as the importance of an input variable at a given point in the input space are shown in Figure 1. The obtained values corresponded to the level of experimental errors, and also showed 
Table I Descriptive statistics of data.

\begin{tabular}{|c|c|c|c|c|c|c|}
\hline Diagnose & Age & Samples & Parameter & Mean \pm SD & Parameter & Mean \pm SD \\
\hline Anem. & $11-19$ years & 33 & \multirow[t]{4}{*}{ WBC $\left(10^{9} / \mathrm{L}\right)$} & $6.211 \pm 2.113^{a}$ & \multirow[t]{4}{*}{ UIBC } & $68.639 \pm 12.910^{a}$ \\
\hline Control & $11-19$ years & 52 & & $6.822 \pm 2.019^{a}$ & & $48.344 \pm 11.406^{b}$ \\
\hline Anem. & $6-24$ months & 56 & & $10.547 \pm 3.834^{b}$ & & $70.887 \pm 17.567^{a}$ \\
\hline Control & $6-24$ months & 32 & & $9.785 \pm 2.919^{b}$ & & $56.334 \pm 9.766 c$ \\
\hline Anem. & $11-19$ years & 33 & \multirow{4}{*}{$\mathrm{RBC}\left(10^{12} / \mathrm{L}\right)$} & $4.474 \pm 0.592^{a}$ & \multirow[t]{4}{*}{ TIBC $(\mu \mathrm{mol} / \mathrm{L})$} & $75.294 \pm 10.605 a^{b}$ \\
\hline Control & $11-19$ years & 52 & & $4.689 \pm 0.465^{a}$ & & $62.652 \pm 9.290 c$ \\
\hline Anem. & $6-24$ months & 56 & & $4.602 \pm 0.663^{a}$ & & $78.057 \pm 13.872^{b}$ \\
\hline Control & 6-24 months & 32 & & $4.746 \pm 0.495^{a}$ & & $69.254 \pm 8.771^{a}$ \\
\hline Anem. & $11-19$ years & 33 & \multirow[t]{4}{*}{$\mathrm{Hb}(\mathrm{g} / \mathrm{L})$} & $96.364 \pm 16.524^{b}$ & \multirow[t]{4}{*}{$\mathrm{CRP}(\mathrm{mg} / \mathrm{L})$} & $0.049 \pm 0.202^{a}$ \\
\hline Control & $11-19$ years & 52 & & $136.481 \pm 11.055^{d}$ & & $0.003 \pm 0.024^{a}$ \\
\hline Anem. & 6-24 months & 56 & & $83.982 \pm 15.409^{a}$ & & $1.291 \pm 7.415^{a}$ \\
\hline Control & $6-24$ months & 32 & & $115.750 \pm 5.565 c$ & & $0.181 \pm 0.690^{a}$ \\
\hline Anem. & $11-19$ years & 33 & \multirow[t]{4}{*}{$\operatorname{PLT}\left(10^{9} / \mathrm{L}\right)$} & $292.485 \pm 79.399^{a}$ & \multirow[t]{4}{*}{ Ferritin $(\mu \mathrm{g} / \mathrm{L})$} & $10.139 \pm 5.162^{a}$ \\
\hline Control & $11-19$ years & 52 & & $217.231 \pm 53.427^{b}$ & & $20.429 \pm 6.721^{b}$ \\
\hline Anem. & $6-24$ months & 56 & & $426.357 \pm 186.214^{c}$ & & $13.502 \pm 8.152^{a}$ \\
\hline Control & $6-24$ months & 32 & & $345.500 \pm 105.856^{a}$ & & $19.859 \pm 11.326^{b}$ \\
\hline Anem. & $11-19$ years & 33 & \multirow[t]{4}{*}{ MCV $\left(10^{-15} / \mathrm{L}\right)$} & $69.582 \pm 9.705^{a}$ & \multirow[t]{4}{*}{ Transferin $(\mathrm{g} / \mathrm{L})$} & $3.506 \pm 0.343^{a}$ \\
\hline Control & $11-19$ years & 52 & & $83.588 \pm 5.264^{c}$ & & $2.740 \pm 0.245^{b}$ \\
\hline Anem. & $6-24$ months & 56 & & $60.420 \pm 9.066^{b}$ & & $3.656 \pm 0.450^{a}$ \\
\hline Control & 6-24 months & 32 & & $72.919 \pm 6.517^{a}$ & & $3.007 \pm 0.368 c$ \\
\hline Anem. & $11-19$ years & 33 & \multirow[t]{4}{*}{$\mathrm{MCH}\left(10^{-12} / \mathrm{L}\right)$} & $20.958 \pm 3.693^{b}$ & \multirow[t]{4}{*}{ Hepcidin $(\mathrm{ng} / \mathrm{mL})$} & $4.1 \pm 18^{a}$ \\
\hline Control & $11-19$ years & 52 & & $29.385 \pm 2.196^{d}$ & & $10 \pm 7^{b}$ \\
\hline Anem. & 6-24 months & 56 & & $17.961 \pm 4.002^{a}$ & & $4.4 \pm 3.1^{a}$ \\
\hline Control & $6-24$ months & 32 & & $24.381 \pm 2.636^{c}$ & & $14 \pm 24^{b}$ \\
\hline Anem. & $11-19$ years & 33 & \multirow[t]{4}{*}{$\mathrm{MCHC}(\mathrm{g} / \mathrm{L})$} & $313.030 \pm 25.618^{a}$ & \multirow[t]{4}{*}{ Rtc (\%) } & $1.770 \pm 0.606^{b}$ \\
\hline Control & $11-19$ years & 52 & & $349.731 \pm 28.398^{b}$ & & $1.152 \pm 0.410^{a}$ \\
\hline Anem. & $6-24$ months & 56 & & $296.107 \pm 29.569^{a}$ & & $1.929 \pm 0.705^{b}$ \\
\hline Control & 6-24 months & 32 & & $336.531 \pm 33.318^{b}$ & & $1.317 \pm 0.268^{a}$ \\
\hline Anem. & $11-19$ years & 33 & \multirow[t]{4}{*}{$\mathrm{Fe}(\mu \mathrm{mol} / \mathrm{L})$} & $6.215 \pm 4.345^{a}$ & \multirow[t]{4}{*}{ TSAT (\%) } & $8.791 \pm 7.320^{a}$ \\
\hline Control & $11-19$ years & 52 & & $14.186 \pm 5.703^{b}$ & & $23.404 \pm 11.010^{c}$ \\
\hline Anem. & $6-24$ months & 56 & & $4.751 \pm 3.249^{a}$ & & $6.998 \pm 6.646^{a}$ \\
\hline Control & $6-24$ months & 32 & & $10.736 \pm 4.766^{c}$ & & $15.583 \pm 7.235^{b}$ \\
\hline
\end{tabular}

a-f Values with the same latter are not statistically different at the $\mathrm{p}<0.05$ level (according to posthoc Tukey's HSD test). Legend: WBC - white blood cells, RBC - Red blood cells, Hb - Hemoglobin, PLT - Platelets, MCH - Mean corpuscular hemoglobin, MCHC - Mean corpuscular hemoglobin concentration, MCV - Mean corpuscular volume, Fe - Iron, UIBC - Unsaturated iron binding capacity, TIBC - Total iron binding capacity, CRP - C-reactive protein, Rtc - Reticulocytes, TSAT - Transferrin saturation. 
Table II Correlation matrix for patients suffering from anemia and control group for 6-24 months and 11-19 years age groups.

\begin{tabular}{|c|c|c|c|c|c|c|c|c|c|c|c|c|c|c|c|}
\hline & RBC & $\mathrm{Hb}$ & PLT & MCV & $\mathrm{MCH}$ & $\mathrm{MCHC}$ & $\mathrm{Fe}$ & UIBC & TIBC & CRP & Feritin & Trans & Hepcidin & Rtc & TSAT \\
\hline WBC & $0.186^{*}$ & $-0.242^{+}$ & $0.500^{+}$ & $-0.313^{+}$ & $-0.316^{+}$ & $-0.233^{+}$ & $-0.155^{*}$ & 0.151 & $0.156^{*}$ & $0.204^{+}$ & & $0.224^{+}$ & & & $-0.154^{*}$ \\
\hline RBC & & $0.202^{+}$ & & $-0.157^{*}$ & $-0.152^{*}$ & & & & & & $0.174^{*}$ & & & $-0.165^{*}$ & \\
\hline $\mathrm{Hb}$ & & & $-0.460^{+}$ & $0.828^{+}$ & $0.885^{+}$ & $0.672^{+}$ & $0.753^{+}$ & $-0.699^{+}$ & $-0.615^{+}$ & & $0.521^{+}$ & $-0.763^{+}$ & & $-0.640^{+}$ & $0.736^{+}$ \\
\hline PLT & & & & $-0.455^{+}$ & $-0.471^{+}$ & $-0.338^{+}$ & $-0.342^{+}$ & $0.286^{+}$ & $0.230^{+}$ & & $-0.202^{+}$ & $0.374^{+}$ & & $0.155^{*}$ & $-0.332^{+}$ \\
\hline MCV & & & & & $0.894^{+}$ & $0.526^{+}$ & $0.618^{+}$ & $-0.643^{+}$ & $-0.561^{+}$ & & $0.381^{+}$ & $-0.654^{+}$ & $0.183^{*}$ & $-0.519^{*}$ & $0.611^{*}$ \\
\hline $\mathrm{MCH}$ & & & & & & $0.781^{+}$ & $0.680^{+}$ & $-0.704^{+}$ & $-0.654^{+}$ & & $0.399^{+}$ & $-0.706^{+}$ & $0.175^{*}$ & $-0.547^{+}$ & $0.692^{+}$ \\
\hline $\mathrm{MCHC}$ & & & & & & & $0.473^{+}$ & $-0.484^{+}$ & $-0.490^{+}$ & & $0.273^{+}$ & $-0.506^{+}$ & & $-0.446^{+}$ & $0.482^{+}$ \\
\hline $\mathrm{Fe}$ & & & & & & & & $-0.744^{+}$ & $-0.550^{+}$ & & $0.489^{+}$ & $-0.623^{+}$ & $0.166^{*}$ & $-0.444^{+}$ & $0.971^{+}$ \\
\hline UIBC & & & & & & & & & $0.915^{+}$ & & $-0.468^{+}$ & $0.676^{+}$ & & $0.452^{+}$ & $-0.819^{+}$ \\
\hline TIBC & & & & & & & & & & & $-0.409^{+}$ & $0.601^{+}$ & & $0.409^{+}$ & $-0.673^{+}$ \\
\hline Feritin & & & & & & & & & & & & $-0.558^{+}$ & $0.322^{+}$ & $-0.328^{+}$ & $0.490^{+}$ \\
\hline Trans & & & & & & & & & & & & & $-0.171^{*}$ & $0.584^{+}$ & $-0.616^{+}$ \\
\hline Hepcidin & & & & & & & & & & & & & & $-0.134^{* *}$ & $0.144^{* *}$ \\
\hline Rtc & & & & & & & & & & & & & & & $-0.426^{+}$ \\
\hline
\end{tabular}

${ }^{+}$Correlation is statistically significant at the $p<0.01$ level; ${ }^{*}$ Correlation is statistically significant at the $p<0.05$ level. Legend: WBC - White blood cells, RBC - Red blood cells, Hb - Hemoglobin, PLT - Platelets, MCH - Mean corpuscular hemoglobin, MCHC - Mean corpuscular hemoglobin concentration, MCV - Mean corpuscular volume, Fe - Iron, UIBC - Unsaturated iron binding capacity, TIBC - Total iron binding capacity, CRP - C-reactive protein, Trans - Transferin, Rtc - Reticulocytes, TSATTransferrin saturation.

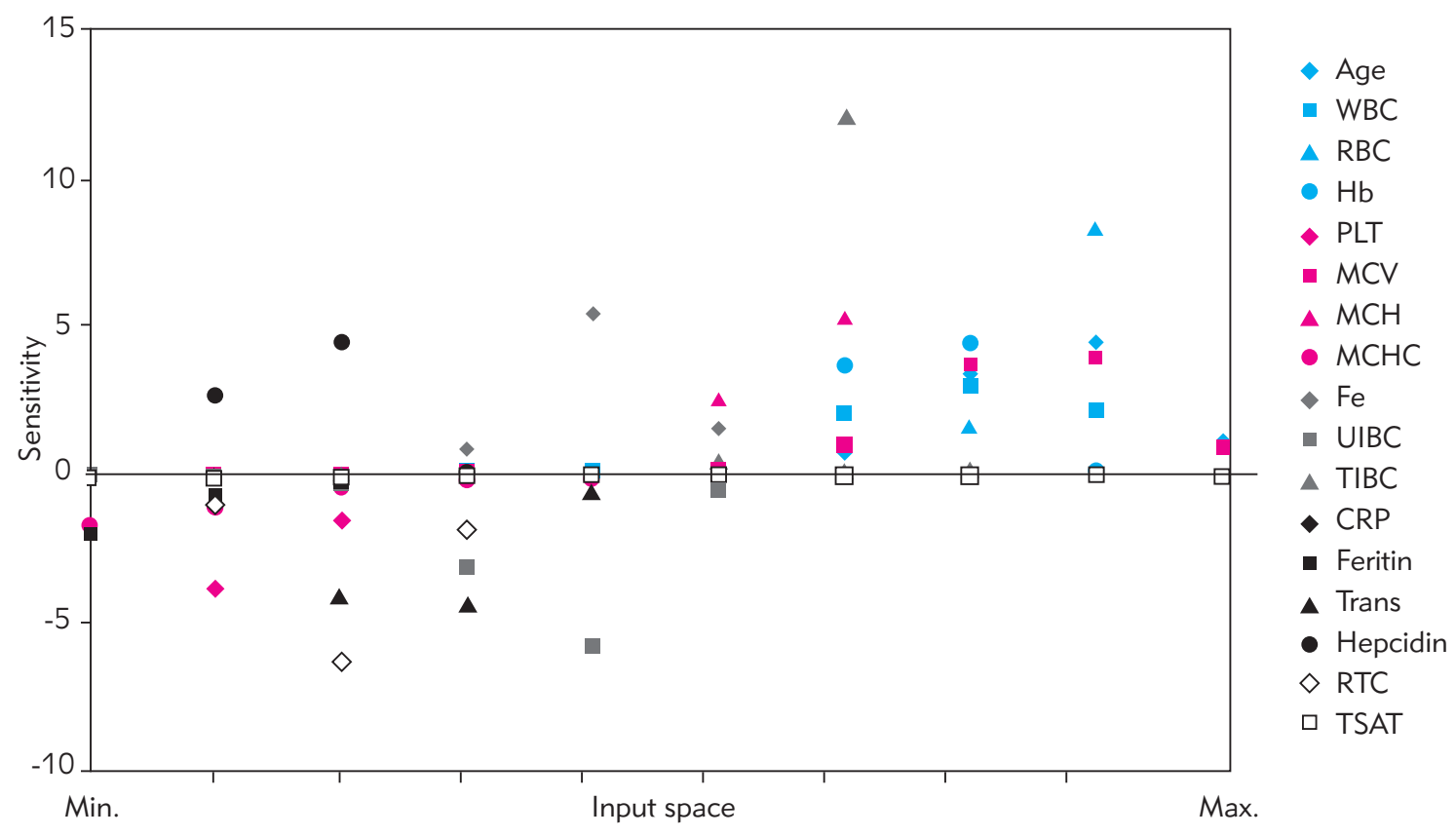

Figure 1 Sensitivity analysis - the influence of the input over the output variables. 
that Age, WBC, RBC, Hb, PLT, MCV, MCH, MCHC, Fe, UIBC, TIBC, CRP, Ferritin, Transferin, Hepcidin, Rtc and TSAT influenced on IDA.

Sensitivity analysis was used to investigate the influence of input variables on the observed outputs, evaluated at specific centile points for each input variable. The influence of the input over the output variables, i.e. calculated changes of the output variables for infinitesimal changes in the input variables are shown in Figure 1.

The more pronounced effect on IDA could be observed by infinitesimal changes in variable Age, closer to the maximum of input space of this variable. It means that if the Age variable is higher, it would be more likely that the IDA would be indicated. The effects of infinitesimal changes in MCV and RBC variables IDA are more indicative closer to the maximums of these input variables (within the tested input spaces, described in the descriptive statistics table). Also, the impacts of small variations in $\mathrm{Hb}, \mathrm{MCH}$ and Fe on IDA determination, could be more easily noticed if they are closer to the higher levels of these variables, closer to the maximum of defined input space. The effect of infinitesimal changes in the PLT on IDA determination, could be observed closer to the maximum level of this variable. According to sensitivity analysis, variables MCHC and CRP had no significant impact on the determination of IDA, which coincide to result of ANOVA for the FOP model. The effect of infinitesimal changes in UIBC, closer to the maximum of input space influences IDA more pronounced, while the impact of small variations in variable Ferritin is more easily observed at the minimum of the input space. The effect of infinitesimal changes in variable Hepcidin, at the lower end of the input space indicates the more pronounced changes in IDA value. The effects of infinitesimal changes in Rtc closer to the maxim of the input space could be more easily indicated in IDA calculation. The variable TSAT expressed no impact on the determination of IDA, according to sensitivity analysis.

\section{Discussion}

Hepcidin is synthesized as a response to the iron body level, inflammation, hypoxia and anemia (14, 27-29). Positive regulators of hepcidin synthesis are increased iron values, infection and/or inflammation, while negative regulators of hepcidin synthesis are iron deficiency, anemia, hypoxia and erythropoiesis $(11,19,30,31)$.

It was suggested at hepcidin concentration exhibits great inter-individual differences and that hepcidin values are influenced by gender and age, with the possibility of the existence of significant difference among populations $(32,33)$.
In addition to the standard parameters of iron metabolism that are used in everyday clinical practice, we measured the serum hepcidin. The tests conducted for adult population have shown different levels of hepcidin, variating for sex and age, however, the results were not consistent. Also, a small number of studies that evaluated hepcidin in children didn't propose the reference value, nor the correlation between hepcidin and sex, age, or iron level concentration in various clinical conditions (19). In the general population, hepcidin levels are significantly lower for women under 50 years of age compared to men in the same age group, and after fifty years of age is similar in both sexes and relatively constant values in the coming decades. This is due to the increased need for iron in women during the reproductive age (34).

In our study, serum hepcidin was determined by ELISA method. The resulting mean value of hepcidin in the age group of 6 to 24 months for patients suffering from anemia was $4.4 \mathrm{ng} / \mathrm{mL}$, while this value reached $14 \mathrm{ng} / \mathrm{mL}$ for the control group. In the age group 11-19 years, for the group of patients suffering from anemia, the mean value of hepcidin was 4.1 $\mathrm{ng} / \mathrm{mL}$, while in the control group this value reached $10 \mathrm{ng} / \mathrm{mL}$. There was no significant difference in mean hepcidin concentration observed between two age groups, but the difference was significant between both IDA age groups and corresponding controls ( $p<0.05)$. According to the literature, a wide range of values on the basis of measurements performed by ELISA test of hepcidin ranged between 29-254 ng/mL for healthy men, and 17-286 ng/mL for healthy women (35). In a study performed by Galeslootet al. (18), which included 2,998 healthy volunteers, it was found that hepcidin serum ranged between $4.1 \mathrm{nmol} / \mathrm{L}$ for premenopausal women and $7.8 \mathrm{nmol} / \mathrm{L}$ for men.

In our study, it was confirmed that there was no significant difference between the mean values of ferritin observed for two age groups, and there was statistically significant difference between patients suffering from anemia and control groups. Since ferritin is a protein of the acute phase of the inflammatory response its value is increased during infection and inflammation, the normal values does not exclude the existence of IDA. Therefore, the level of ferritin should be correlated with other markers of inflammation $(36,37)$.

Although hepcidin acts as an acute phase reactant in the inflammatory response, as well as ferritin, the hepcidin value declines more rapidly after the removal of infectious or inflammatory signal. According to Uijterschout et al. (29), for children with iron deficiency in reconvalescence period, hepcidin serum is decreased in order to allow the intestinal absorption of iron for erythrocytopoiesis, while the ferritin value in this period is still above the limit value (cut off) that 
is indicative for the iron deficiency. Thus, hepcidin represents a more sensitive indicator of iron deficiency than ferritin, however, the clinical use of hepcidin is being hampered by the lack of defined reference values for the specific age (23).

From Figure 1 it can be noted that hepcidin has an important role in the definition of the neural network model. It is good predictor of iron status and it can suggest whether the patient is or is not iron deficient. This model suggests that hepcidin is far better indicator of IDA or iron deficiency than the $\mathrm{Hb}$ itself $(\mathrm{Hb}$ is not even statistically significant in the linear model). Hepcidin can be considered as a factor that indicates iron deficiency much before $\mathrm{Hb}$.

It is not influenced by age which makes it a more sensitive indicator of the iron body stores. Besides this, serum hepcidin is a reliable biological marker of the iron deficiency.

\section{References}

1. Marn H, Critchley JA. Accuracy of the WHO hemoglobin colour scale for the diagnosis of anemia in primary health-care settings in low-income countries: a systematic review and meta-analysis. Lancet Glob Health 2016; 4: $251-65$.

2. Polin V, Coriat R, Perkins G, Dhooge M, Abitbol V, Leblanc $S$, et al. Iron deficiency: from diagnosis to treatment. Digest Liver Dis 2013; 45: 803-9.

3. Anand T, Rahi M, Sharma P, Ingle GK. Issues in prevention of iron deficiency anemia in India. Nutrition 2014; 30: $764-70$.

4. Pettit K, Rowley J, Brown N. Iron deficiency. Pediatrics and Child Health 2011; 21(8): 339-43.

5. Peirano PD, Algarin CR, Chamorro RA, Reyes SC, Duran SA, Garrido Ml et al. Sleep alterations and iron deficiency anemia in infancy. Sleep Med 2010; 11: 637-42.

6. Stoffman N, Brugnara C, Woods ER. An algorithm using reticulocyte hemoglobin content $(\mathrm{CHr})$ measurement in screening adolescents for iron deficiency. J Adolescent Health 2005; 36: 529.1-6.

7. Kolarović J, Ćulafić J, Čabarkapa V, Vučković N, Vučković $D$, Bodroža-Solarov $M$. The incidence of anemia in the adult working population of Vojvodina. J Med Biochem 2014; 33(3): 278-83.

8. Kanamori Y, Murakami M, Matsui T, Funaba M. Hepcidin expression in liver cells: evaluation of mRNA levels and transcriptional regulation. Gene 2014; 546: 50-5.

9. Ruchala P, Nemeth E. The pathophysiology and pharmacology of hepcidin. Trends Pharmacol Sci 2014; 35(3): 155-61.

10. Brugnara C. Reference values in infancy and childhood, in: Nathan and Oski's hematology of infancy and childhood. 6th edition. Philadelphia: WB Saunders, 2003: 1835-64.

\section{Contribution statement}

CJ and $\mathrm{KJ}$ conceived the idea for the study. CV, NS and SA contributed to the design of the research. All authors were involved in data collection. PL analyzed the data. BSM coordinated funding for the project. All authors edited and approved the final version of the manuscript.

Acknowledgments. This work was funded by the Ministry of Science and Technology of Serbia, project number III46005

\section{Conflict of interest statement}

The authors stated that they have no conflicts of interest.

11. Coates TD. Physiology and pathophysiology of iron in hemoglobin-associated diseases. Free Radical Bio Med 2014; 72: 23-40.

12. Wolff F, Deleers M, Melot C, Gulbis B, Cotton F. Hepcidin25: Measurement by LC-MS/MS in serum and urine, reference ranges and urinary fractional excretion. Clin Chim Acta 2013; 423: 99-104.

13. Pietrangelo A. Hepcidin in human iron disorders: Therapeutic implications. J Hepatol 2011; 54: 173-81.

14. Singh B, Arora S, Agrawal P, Gupta SK. Hepcidin: A novel peptide hormone regulating iron metabolism. Clin Chim Acta 2011; 412: 823-30.

15. Eleftheriadis T, Antoniadi G, Antoniadis N, Liakopoulos $\mathrm{V}$, Stefanidis I. Hepcidin and anemia of hemodialysis. Journal of Nephrology and Renal Transplantation 2009; 2(3): 42-53.

16. Clark RJ, Tan CC, Preza GC, Nemeth E, Ganz T, Craik DJ. Understanding the structure/activity relationships of the iron regulatory peptide hepcidin. Chem Biol 2011; 18: 336-43.

17. Keel SB, Doty R, Liu L, Nemeth E, Cherian S, Ganz T, et al. Evidence that the expression of transferrin receptor 1 on erythroid marrow cells mediates hepcidin suppression in the liver. Exp Hematol 2015; 43: 469-78.

18. Galesloot TE, Vermeulen SH, Geurts-Moespot AJ, et al. Serum hepcidin: reference ranges and biochemical correlates in the general population. Blood 2011; 117: 218-25.

19. Cangemi G, Pistorio A, Miano M, Gattorno M, Acquila $M$, Bicocchi MP, et al. Diagnostic potential of hepcidin testing in pediatrics. Eur J Haematol 2013; 90: 323-30.

20. Rehu M, Punnonen K, Ostland V, et al. Maternal serum hepcidin is low at term and independent of cord blood iron status. Eur J Haematol 2010; 85: 345-52. 
21. Muller KF, Lorenz L, Poets CF, Westerman M, Franz AR. Hepcidin concentrations in serum and urine correlate with iron homeostasis in preterm infants. J Pediatr 2012; 160: 949-53.

22. Choi HS, Song SH, Lee JH, Kim Hj, Yang HR. Serum hepcidin levels and iron parameters in children with iron deficiency. Korean J Hematol 2012; 47: 286-92.

23. Taylor BJ. Methods and procedures for the verification and validation of artificial neural networks. Springer Science+Business Media, New York, USA, 2006.

24. Pezo L, Ćurčić B, Filipović V, Nićetin M, Koprivica G, Mišljenović N, Lević Lj. Artificial neural network model of pork meat cubes osmotic dehydration. Hemijska industrija 2013; 67: 465-75.

25. Basheer LA, Hajmeer M. Artificial neural networks: fundamentals, computing, design, and application. J Microbiol Meth 2000; 43: 3-31.

26. Chattopadhyaya PB, Rangarajana R. Application of ANN in sketching spatial nonli-nearity of unconfined aquifer in agricultural ba-sin. Agricultural Water Management 2014; 133: 81-91.

27. Zhang $X$, Rovin BH. Hepcidin expression by human monocytes in response to adhesion and pro-inflammatory cytokines. BBA-Gen Subjects 2010; 1800: 1262-7.

28. Jiang $F, Y u$ WJ, Wang $X H$, Tang $Y T$, Guo $L$, Jiao $X Y$. Regulation of hepcidin through GDF-15 in cancer-ralated anemia. Clin Chim Acta 2014; 428: 14-9.

29. Uijterschout L, Swinkels DW, Akkermans MD, Zandstra T, Nuijsink M, Hendriks D, et al. The value of soluble transferrin receptor and hepcidin in the assessment of iron sta- tus in children with cystic fibrosis. J Cyst Fibros 2014; 13(6): 639-44.

30. Panjeta M, Tahirović I, Sofić E, Ćorić J, Dervišević A. Interpretation of erythropoietin and haemoglobin levels in patients with various stages of chronic kidney disease. J Med Biochem 2017; 36:145-52.

31. Silva B, Faustino P. An overview of molecular basis of iron metabolism regulation and the associated pathologies. BBA-Mol Basis Dis 2015; 1852: 1347-59.

32. Grebenchtchikov N, Geurts-Moespot AJ, Kroot JJ, Den Heijer M, Tjalsma H, Swinkels DW, et al. High sensitive radioimmunoassay for human serum hepcidin. $\mathrm{Br} \mathrm{J}$ Haematol 2009; 146(3): 317-25.

33. Ganz T, Nemeth E. Hepcidin and iron homeostasis. BBAMol Cell Res 2012; 1823: 1434-43.

34. Campostrini N, Traglia M, Martinelli N, Corbella $M$, Cocca M, Manna D, et al. Serum levels of the hepcidin20 isoform in a large general population: The Val Borbera study. J Proteomics 2012; 76: 28-35.

35. Tussing-Humphreys L, Pustacioglu C, Nemeth E, Braunschweig $C$. Rethinking iron regulation and assessment in iron deficiency, anemia of chronic disease and obesity: Introducing hepcidin. J Acad Nutr Diet 2012; 112: 391400.

36. Balarayan J, Ramakrishnan U, Ozaltin E, Shankar AH, Subramanian SV. Anemia in low-income and middleincome countries. Lancet 2011; 378: 2123-35.

37. Sanad M, Gharib AF. Urinary hepcidin level as an early predictor of iron deficiency in children: A case control study. Ital J Pediatr 2011; 37: 37. 